\title{
Land Inequality Trends and Drivers
}

\author{
Marc C. A. Wegerif ${ }^{1, *(1)}$ and Arantxa Guereña ${ }^{2}$ \\ 1 Development Studies, Department of Anthropology and Archaeology, University of Pretoria, \\ Hatfield 0028, South Africa \\ 2 Robledo de Chavela, 28294 Madrid, Spain; arantxacr@gmail.com \\ * Correspondence: marc.wegerif@up.ac.za; Tel.: +27-82-797-8150
}

Received: 5 December 2019; Accepted: 25 March 2020; Published: 28 March 2020

\begin{abstract}
Land related inequality is a central component of the wider inequality that is one of the burning issues of our society today. It affects us all and directly determines the quality of life for billions of people who depend on land and related resources for their livelihoods. This paper explores land inequality based on a wide scoping of available information and identifies the main trends and their drivers. A wider conceptualization of what constitutes land inequality is suggested in response to shifts in how power is concentrated within the agri-food system. Land inequality is the difference in the quantity and value of land people have access to, the relative strengths of their land tenure rights, and about the appropriation of value derived from the land and its use. More data gathering and research needs to be done to better understand and monitor land inequality. Despite data limitations, what can be seen globally is a growing concentration of land in larger holdings leaving the majority of farmers, along with indigenous people and other communities, with less land. As importantly, elites and large corporations are appropriating more of the value within the agri-food sector, leaving farmers and workers with a shrinking proportion of the value produced. A framework is offered to explain the self-perpetuating nature of land inequalities that involve the mutually reinforcing concentration of both wealth and power. This is an unsustainable situation that can only be effectively addressed through challenging the fundamental drivers of accumulation by the few.
\end{abstract}

Keywords: land; inequality; development; land reform; agrarian reform; agriculture; politics; change

\section{Introduction}

This paper gives a concise overview of land inequality introducing new ways that we need to be thinking about this age old conundrum. It is based on a review of a wide range of existing reports and data, combining some of that data in new ways. This relook at land inequality is needed in the context of increasing global wealth and income inequality over the last decades, of which land inequality is one part, and the changing nature of control and wealth appropriation related to land and production on land. We explore what the main trends in land inequality are and what the implications are for land and agrarian reforms and development. We also identifying gaps and challenges to be addressed for more effective tracking and addressing of land inequality in the future.

\section{Why Land Inequality Matters}

Land has historically been essential to people having food, a home, an income, and influence. Despite a smaller proportion of people being directly dependent on land today, the actual number of people in rural areas and who rely on land for their livelihoods is still growing [1,2]. Those depending on land include many of the poorest, with three in every four people living in poverty depending on agriculture related activities for their livelihoods [3]. In areas where the majority of people depend 
on agriculture for food and livelihoods, equitable access to land, especially for women, has a major role to play in the eradication of hunger and other development benefits. This is not just due to food production, but also the job creation in agriculture and the non-farm jobs, especially in agri-food processing, that a thriving agricultural sector, as well as more diversified land uses, can contribute to [4-12].

More equally distributed land has been found to have contributed to the creation of more equal societies that foster sustained growth and development on more solid foundations [13,14]. Deininger (2003) and Easterly (2007) show, based on a cross-country analysis, that only two of the 15 developing countries with very unequal land distribution managed to grow their economies at more than $2.5 \%$ over the period 1960-1992 [15]. Sokoloff and Engerman [16] compared the evolution of North America and South America, finding that large inequalities in land holdings were the basis for political inequalities that were used to block investment in improved education for the majority. Galor, et al. [17] confirm the same dynamics from a study of the development of spending on education, compared to levels of land inequality across states in the USA. The lack of investment in education in places with high land inequality thwarted the human capital and institutional formation that were needed for economic growth in new industries and the entrenchment of democracy, resulting in a long term divergence in growth and progress between countries that invested in education and those that didn't. These lessons continue to be important for understanding how land inequality can shape priorities and progress and are of particular importance for countries transitioning from an agrarian economy today.

Secure and more equally distributed land rights have been identified as beneficial for social and economic progress, contributing among other things to democracy, peace, productivity, and gender equality. The positive effects are better achieved when combined with other interventions, such as good local market links, agricultural support services that work for family farmers, and improvements in health and education services $[6,11,18,19]$. This has been agreed in international policy frameworks [20-24], for example, the Sustainable Development Goals (SDGs), adopted in 2015, include a number of land inequality specific targets and indicators (i.e., SDG indicators 1.4.2. 5.a.1. and 5.a.2).

Changes in the global and national economies are bringing new pressures that people respond to in different ways changing their land uses, livelihood strategies and life styles in rural areas in what some describe as "new rurality" $[25,26]$. The nature of the 'peasant' and what is 'agrarian' is shifting as are relationships with the land, requiring us to reconsider the rural, but not necessarily meaning land inequalities are less important [27].

For many people land is bound up with their spiritual and cultural lives and sense of identity. Some argue that, far from seeing land as a commodity for us to own, we should rather see ourselves as belonging to the land and responsible for its wellbeing [28]. Whether directly linked to land or not, land is vital for all of us, and future generations, as a common good that we depend on for such essentials as clean air and water, and biodiversity.

\section{Understanding Land Inequality}

Land inequality is, at a basic level, about the differences in the size of land area that people can access and have rights to and the strength of the tenure rights they have to that land. We argue, however, that it is also about the ability to control the use of land and the benefits from that land and what is produced on it. This wider conceptualization of land inequality is increasingly important in a world where (1) "accumulation by dispossession" has again become more important than accumulation through "expanded reproduction" [29,30], and; (2) the forms of appropriation and distribution of value have become more complex, moving from a simple land/ground rent to what Andreucci, García-Lamarca, Wedekind and Swyngedouw [29] refer to as "value grabbing".

The approach of this paper, therefore, involves four axes along which to analyze land inequality: (1) The size and/or value of land that people access or hold with some people holding large tracts of high value land and others having no land, or small amounts of low value land; (2) the level of security 
of tenure that people have including the ability to defend their land when encroached upon and to get justice if land rights are taken away. This is harder to measure than land sizes and value, but just as important. Some people have extremely strong rights to land that are very unlikely to be violated, while others may be registered as land owners, but due to social or political factors could have the land taken at any time and would not be able to get justice in the courts or elsewhere; (3) the actual control that people have, which includes their decision-making power over land. This goes beyond the tenure rights contained in the land administration system. It can be affected by factors like social norms constraining women from planting certain crops, state imposed decisions about what crops should be grown where, or corporate control of inputs and markets that severely limit the viability of certain crops while aggressively promoting others, and; (4) their control of the benefits from the land, i.e., the ability to appropriate value from the land. Again, factors from social dictates at the micro level (e.g., men appropriating certain cash crops), to political interference (e.g., imposed marketing boards), access to infrastructure (e.g., roads and irrigation), or a corporate concentration of control over required finance as well as control of processing facilities and markets, can severely limit people's options, even if they have strong tenure rights to land (see Figure 1).

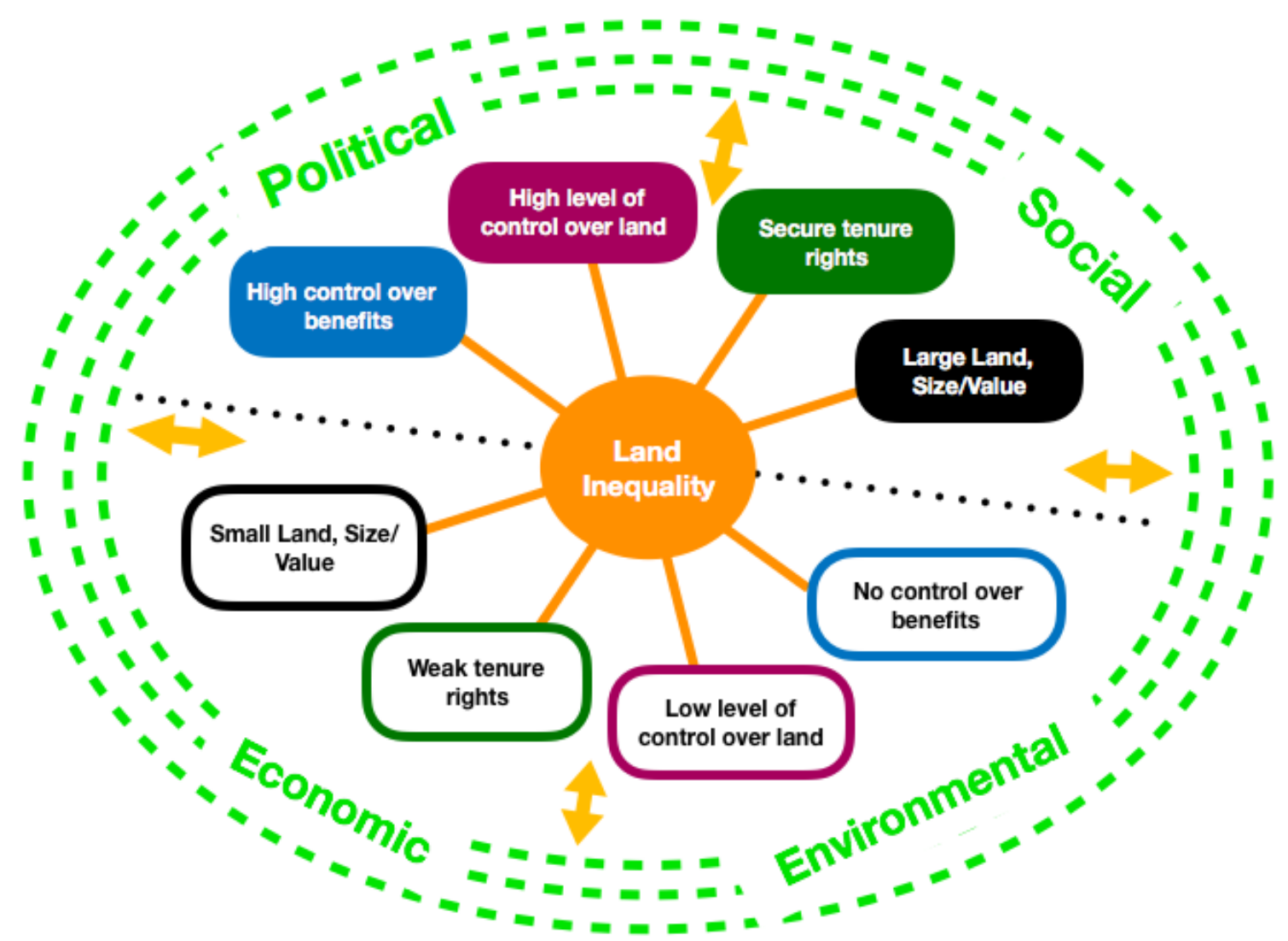

Figure 1. Land and inequality conceptualized (Source: the authors).

It is important to also look at land relations within the context that they contribute to shaping and that also shapes them. These are summarized as social, political, economic, and environmental factors-all of which impact all aspects of land inequality - and are represented in green on the outside edge of Figure 1. Social factors-most obviously in dynamics such as gender power relations, but also manifesting in discrimination against particular ethnic groups and castes or classes-can shape the extent to which certain people gain rights to land and the strength of those rights. These social norms can be just as influential in markets for outputs and for farming inputs, thus constraining the ability of some to benefit from land use. Political power often shapes outcomes for communities attempting to defend their land rights, and in turn, ownership of land can be a source of political power. Political 
power is used to influence land administration regimes, justice systems, and marketing and financial services policies and practices, all of which shape the levels of equality along the four axes of land inequality we identify. The nature of the wider economy, including the agri-food sector, will clearly enable more or less beneficial land use. Those with economic power, if not adequately constrained by policies and regulations, can have enormous power to dictate farm production and terms of trade that make certain land uses more or less viable. We are becoming more aware, with the increasing impacts of climate change as well as loss of biodiversity and soil fertility, of how the environment is shaping land use opportunities, while land use choices are also having impacts on the environment. In water scarce areas, for example, the inequality between those with irrigation land and those without is becoming far greater as rainfall becomes more unreliable.

\section{Land Inequality, Further Considerations}

Most measures of inequality focus on the individual and on the changes in the aggregate income of individuals grouped according to income or wealth percentiles, in what is referred to as vertical inequality. Such an approach in relation to land tends to look at the value and/or hectares of land individuals own. Examining horizontal inequalities involves looking at inequalities that arise between particular groups of people defined by some form of common identity based on embedded values of particular societies [31-33]. This is of particular importance in relation to land, as gender, ethnic, caste, racial, and other forms of group identity are often used to discriminate against people in relation to land rights and access.

Bartlett [31], p.282 has pointed out: "Whether and to what extent economic inequality is a problem also depends upon what goods are freely available, without purchase." This is a pertinent point in relation to land and benefits from the land. In some countries public land is available to all for activities, such as grazing and recreation, and in some cases public land can be allocated to people without charge, or at low administrative rather than market costs [34]. At the same time, the presence of public land and state custodianship of land does not necessarily mean greater equality of access or security, as state control has often been used to exclude the poorest people and to favor elites, even in supporting the grabbing of community and public land [35-37]. For many people, having access to land themselves is not necessary for them to secure food to eat, as they have other sources of income and food is available to be purchased. If all countries were able to transition to economies that could provide sufficient urban industrial or service sector jobs, we could worry less about direct land inequality, but these jobs are not materializing in most lower and middle income countries. This requires us to maximize the potential of land and agriculture to produce food, to create economic opportunities including on and of off-farm jobs in food and agriculture processing and trading. These benefits have been found to be greater within equitable territorial and symbiotic food and agricultural systems that are also effective in providing accessible food for urban residents even in the largest cities [6,7,38-40].

Up to 2.5 billion people around the world depend on land held under forms of collective tenure for their homes, incomes, food, medicine, and cultural identity. These communities hold around $65 \%$ of the world's land, but have formally recognized rights over just 10\% [41]. Many of these are Indigenous communities, and almost all Indigenous communities use collective tenure arrangements based on some form of customary land rights and administration [42,43]. The level of security of families and individuals within such communities depends on the strength of rights of the community as a whole and the rules, social norms, and practices within the community [36,42,44-46]. Ensuring strong rights requires that they are legally and socially recognized and that people and communities have recourse to get justice if their land rights are violated. This is too often not the case for indigenous and other rural communities who rarely have the same access to courts and to political decision makers that elite individuals and large corporations have. The diversity of practices, the collective nature of rights, the weakness in practice of some of these rights, and the lack of documentation pose particular challenges for measuring land inequality in communal land holding. 
In addition to direct gender inequalities in rights and access to land, women carry far more responsibility than men for family reproduction and unpaid care work, particularly in areas such as child care, ensuring that food is available for the family, and taking care of the sick at home and in the community. This has an impact on women's time, finances, and well-being, thus affecting their ability to assert land rights and benefit from land use. Interventions, such as those to increase agricultural production, that do not take this into consideration, can add to women's burden with negative outcomes for their quality of life [9,47-49].

\section{The Data: What We Know and We Don't Know}

There are currently limitations to the amount and reliability of data relating to land inequality. The ways that land inequalities are measured and the challenges involved are elaborated in a 2019 International Land Coalition (ILC) publication on land inequality [50]. Different countries capture different data in their land administration systems and in agricultural surveys (most of which are very dated), making them hard to compare. There are also large gaps such as very few countries capturing information on the extent of land holding on communal land and many countries not gathering sex disaggregated data [50]. For example, when the government of South Africa carried out a land audit they were only able to identify the land owners and rights holders on private land, not on communal land where most of the rural population live. Further, on $61 \%$ of that private land they could not identify the sex, race, or nationality of the owners because the land was registered in the names of companies and trusts for which they didn't have those details available [51].

Globally, estimates of the number of farms range from around 570 million [52] to just under 610 million [53], using a total agricultural land area of around 5 billion hectares [54]. An indicator of the level of inequality in agricultural land holding is that $84 \%$ of farms are smaller than 2 hectares, and account for $12 \%$ of the world's farmland, which leaves just $16 \%$ of farms controlling $88 \%$ of all farmland [52]. Based on the varied definitions of "small" farms in different countries across the world, it has been calculated that $92.3 \%$ of farms are "small" and use just $24.7 \%$ of the world's farmland [53]. It is difficult to make a direct comparison of global farm size figures overtime, due to less countries having gathered this data in the past, countries gathering the data at different times, and inter-country differences and changes in data gathered [52,55].

There is a clear trend towards larger average farm sizes in wealthier and land abundant countries, with declining average farm sizes in developing countries [52,56,57]. For example, average farm sizes in Europe grew from 14.4 hectares in 2010 to 16.1 in 2013 [58] and half of all agricultural land in 2013 was controlled by only $3.1 \%$ of all farms, while small farms (less than 10 hectares), representing three-quarters of all farms, controlled only $11 \%$ of the agricultural area [59]. Two-thirds of farms in Europe have disappeared in the last 30 years [60], cheap food imports have destroyed the livelihoods of farmers in parts of Europe and large corporate land deals have targeted land used by smallholder farmers, especially in Eastern Europe [61]. For now, however, the situation remains relatively egalitarian in Europe compared with North America and Latin America with average farm sizes of 170 hectares in the USA and 590 hectares in Argentina. In the extreme case of Colombia just $1 \%$ of landowners hold over $80 \%$ of the agricultural land, with the largest landowners controlling over 50,000 hectares each [62]. Despite the concentration of ownership at the top end, the average farm sizes across Latin America and the Caribbean decreased from 80 hectares around 1960 to 54 hectares in 2000 [52] due to declining small farm sizes. It is now the continent with the most extreme land inequality, with a Gini coefficient for land of 0.85 (Asia is 0.55) [63]. Despite the high level of urbanization in Latin America, this land inequality is continuing to have negative impacts, especially in distorting pollical power, leaving too many people landless, and contributing to conflict [62,64].

Meanwhile, average farm sizes are in decline across Asia and Africa and are now below 2 hectares per farm in many countries [52]. In South Asia farm sizes halved from an average of 2.6 hectares around 1960, to just 1.3 hectares in 2000 [52]. However, these average figures miss the creation of an increasingly unequal "bimodal" world agricultural sector. While the mass of poorer people struggle to 
survive on increasingly small pieces of land, there is a fast growth of medium-scale farms [57] and large land deals and corporate investments are establishing mega-farms $[35,53,61,65]$, trends that are elaborated in Section 4 below.

The figures show an overall increasing concentration of land in a few, often powerful and well connected hands, while the vast majority of farmers who depend on land are finding it harder to survive on smaller land parcels. Those holding onto and gaining large tracts of land often use their political influence to do so and to ensure economic policies favorable to their business model and to capture state resources for agriculture and development. In a brazen example of this, politicians in Hungary (and other countries) have utilized tens, if not hundreds of millions, of Euros of European Union agriculture funding to create enormous land holdings and farm operations for themselves and their friends and business associates [66].

There is much, of course, that is not revealed about land holdings by these global figures, such as important differences between regions and countries and land fragmentation in the sense of one farmer's land holding being in multiple parts (see below). Even harder to get a clear picture of are other factors of land inequality, such as the differing levels of rights and control that farmers have, with many smaller-scale farmers facing serious obstacles in defending their land rights, and unequal access to markets.

Land fragmentation is commonly used to refer to the process of land holdings getting smaller as well as to the phenomena of one farmer's land holding being made up of several smaller parcels of land that are not necessarily contiguous, nor evenly shaped $[67,68]$. Fragmentation is rather hard to measure and is not well covered in existing data [68]. The land size data referred to above considers fragmentation in the sense that the figures are based on surveys that count the total land held by a household, so cover all land held by that household even it is in separate parcels. The figures also hide land fragmentation in the sense that they do not reveal if household land holdings are made up of one piece of land, or split across multiple holdings.

Land fragmentation has mixed implications for production. In some contexts, it is seen as a disadvantage as it can thwart or reduce the effectiveness of greater mechanization. In other contexts, land fragmentation is an advantage as it allows the farmer to spread risk and have a diversity of crops on different pieces of land that may have different qualities. Land consolidation efforts, as a response to fragmentation, have been common in Europe and it would appear that such efforts can be more beneficial if well managed and within an economy that has more off-farm job opportunities and capital for investment in mechanization $[67,69]$. Land consolidation is likely to be less beneficial where there are labor surpluses and few opportunities off-farm. The nature of land, crops, and land administration also determine the impacts of fragmentation, as they do farm-size efficiency, and the desirability of land consolidation that should therefore be considered on a case by case basis in each context.

The exact scale of gender inequality in land rights is contested, with inadequate and often incompatible ways of measuring it, but its existence is clear; patriarchy and discrimination against women leaves them with weaker rights to less and poorer-quality land [9,70-72]. Standing between formal equality of rights, now recognized in most laws, there are entrenched cultural norms and institutional barriers that reproduce historical exclusion of women [72,73]. Given that on average women earn less than men they are also disadvantaged in land markets [74]. Almost universally, when land tenure is formally registered, more land is registered to men than to women. Across all tenure systems, within communities and households, women have less decision-making power and control over land than men. Often, women access land through male family members (their husbands, fathers, or sons). This leaves them with less control over land, less right to inherit, and more vulnerable to eviction and dispossession, especially if relationships sour $[9,10,75]$.

Across the European Union, women's agricultural land holdings average 7.6 hectares compared with an average of 19.5 hectares owned by men; also, women control only $28 \%$ of all agricultural land holdings and $13 \%$ of the land [56]. In Latin America, women make up fewer than $12 \%$ of land reform beneficiaries [76] and on average only $18 \%$ of farms in the region are in women's hands, ranging 
from $8 \%$ in Guatemala to $30 \%$ in Peru [77]. In Africa there are a few countries that report having gender equality in land holdings. For example, in both Cape Verde and Rwanda over 50\% of land titles are in women's names. The extent of land controlled by women is, however, likely to be less than that controlled by men, due to women having smaller farms and legally registered rights not always being enjoyed due to discriminatory social norms and practices [73,77]. Other African countries show much higher gender inequalities, with just $9.1 \%$ of land holdings in women's names in Senegal, for example [77]. The situation in Asia appears to be worse, with women having a very small share of land holdings: from $4.6 \%$ in Bangladesh and $8.8 \%$ in Indonesia to a high of $27.4 \%$ in Thailand [77].

The figures mentioned above, do not give us the full picture of the nature of land rights and women's and men's differentiated enjoyment of these rights. Most data gathering on land rights fails to adequately address the complexity, the household dynamics, and gender roles, and many lack sufficient sample sizes and credible counterfactuals [4]. They do not tell us about the power relations that so often exist within families. They tell us even less about the challenges women face in accessing finance, technology and markets. There is also a dearth of available information on the extent to which women face systematic discrimination when seeking justice for land rights violations.

Landlessness and land poverty constitute a growing crisis. Many of those affected still depend on land for their livelihoods and often work as temporary, vulnerable, and underpaid laborers in agri-business where they are in a weak negotiating position as they have no options left for independent production [78-80]. A study in five African countries revealed that roughly a quarter of agricultural households were virtually landless, controlling less than 0.1 hectares per person [81]. In Bangladesh, $29 \%$ of rural households own no farmland at all, with a total of 8.7 million landless rural households as a result of land pressures and environmental changes [82].

\section{Trends and Drivers of Land Inequality}

Inequality is self-perpetuating, since it is at the same time a cause and a consequence in a vicious cycle where public policies are shaped in ways that advantage those at the top, at the expense of the rest of society [83]. Economic elites use their wealth and political power to influence public policy or directly take up powerful political positions in order to maintain their privileges. In this way, landed elites are in a position to promote policies-in local, national, and international spaces-that will not only protect them and their land and wealth, but also enable further accumulation of wealth and power [64,84-86]. This involves a range of inter-related, mutually reinforcing factors that can be summarized as: (1) A dominant (hegemonic) view of "modernization" and "progress" that is used to justify actions that drive inequality; (2) historic, normally unjustly created, conditions of wealth and power inequality that are built on, using approaches sanctioned by the dominant paradigm; (3) a stronger position of the wealthier elite to influence policies in their favor, enabling further accumulation; (4) the exercise of wealth and power to influence a wide range of other actors who then support and reinforce the dominant paradigm and its implementation. This often includes academic institutions, non-governmental organizations, and philanthropists all of whom tend to align their work to the interests of those with money and power, and; (5) the concentration of power results in critical or alternative views being marginalized, while frustration at levels of poverty and inequality result in counter-movements that can be either destructive or constructive (or a combination of these) in finding ways to overcome inequality (Figure 2).

\subsection{Historic Roots and the Extractivist Paradigm of Modernisation}

Countries with colonial histories tend to have higher levels of inequality today, as a result of accumulation by dispossession and imposed systems of production and distribution that were never intended to serve the majority. This was combined with gender-, ethnic-, or caste-based discrimination, which was used as part of a narrative to justify inequalities and as part of colonial means of control and exploitation $[23,87]$. Based on land appropriation, enslaved labor, and the exploitation of nature, 
a dominant extractive model was established to supply minerals and raw materials to growing economies in Europe [88]. This approach disregarded ecology and the needs of local people.

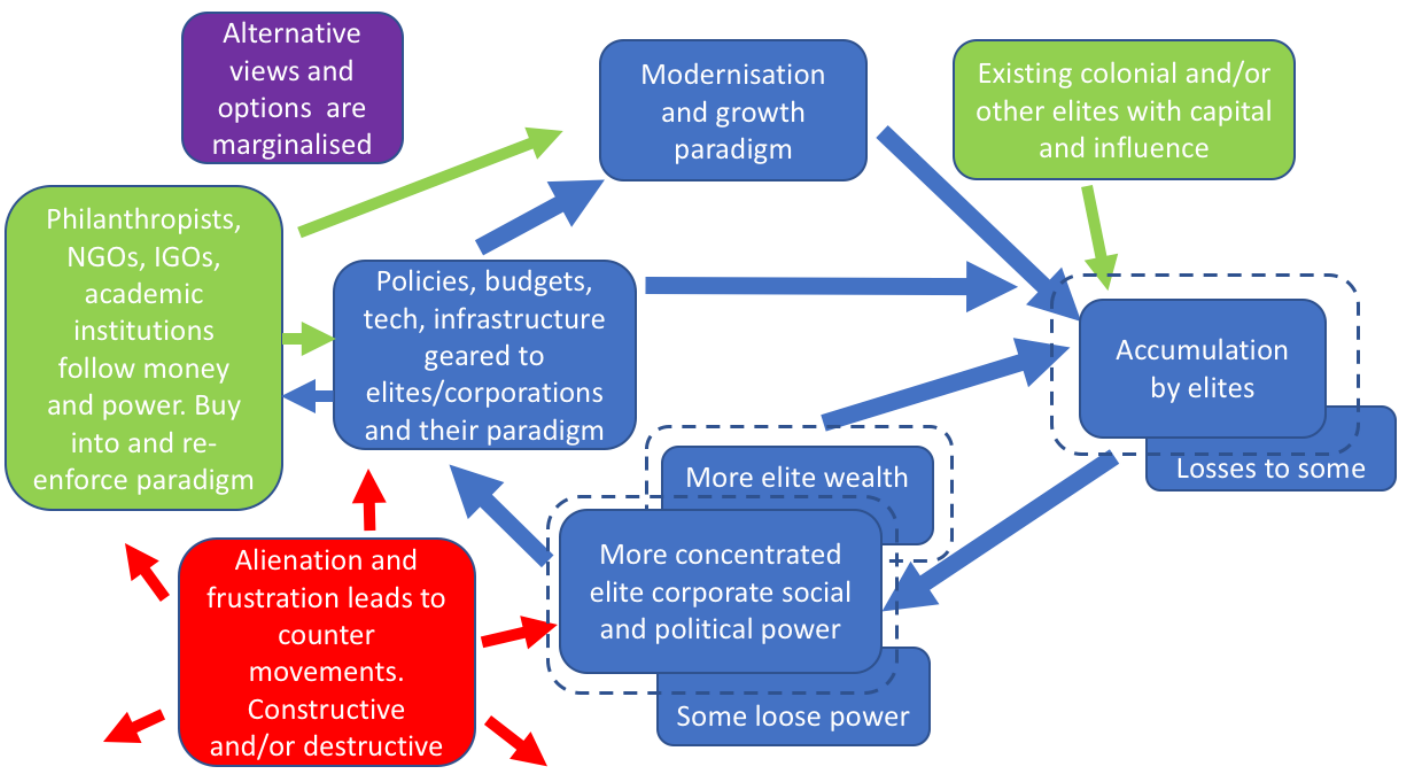

Figure 2. Reinforcing cycles of land and inequality (Source: the authors).

A dual agricultural system emerged with, on one side, large-scale plantations administered through state institutions; on the other, subsistence-oriented small farms on land predominately governed by customary authorities and with a lower provision of public services [89]. This dual system based on a deep-seated and narrow modernization paradigm that includes productivism (the belief that productivity and growth are the purpose of human organization), combined with discrimination against the agricultural practices of the majority, has informed most agrarian policies [90]. This has been used to justify the concentration—by force when needed—of land and non-regenerative uses of land, water, and forests.

The processes of liberation from colonialism did not end the inequalities created, but rather saw efforts by those in power during colonial times to hold onto their wealth. Colonial elites established new alliances and indigenous elites emerged that maintained the structures of privilege and inequality to their advantage $[86,91]$. More recently many states have supported new drives to spread the extractivist model to what they argue are underutilized lands, leading to extensive territories being allocated to investors without consideration of prior rights, triggering further dispossession, and in some cases serious land conflicts with Indigenous communities [92].

With heightened competition for natural resources, violence against people defending land and environmental rights is increasing. 2018 set the unfortunate new record of 321 human rights defenders murdered in 27 different countries. Almost $80 \%$ of them were defenders of land, Indigenous peoples, and the environment, an increase from $67 \%$ in 2017. Agri-business has become the sector linked to most deaths, with 46 defenders killed in 2017, overtaking mining for the first time [93].

\subsection{A New Cycle of Accumulation by a Few}

Today, there is a new cycle of accumulation by dispossession $[29,30]$ and voices calling for more of the world's land to be put under technology- and capital-intensive production in order to meet an increasing global demand for food [94]. The global land area under soybean cultivation is set to increase by one-third to 125 million hectares by 2050, and the sugarcane area by $28 \%$ to 27 million hectares [95]. As for edible palm oil, the 15 million hectares under production now is expected to double by 2050 [96]. Much of this expansion will happen in Africa, Asia, and Latin America, despite 
the argument that land is available on these continents being widely challenged with warnings about potential violations of community land rights and increasing inequality [97,98].

The food price shocks of 2007 and 2008, coupled with the global financial crisis and the demand for agro-based energy, stimulated a wave of large-scale land acquisitions. The Land Matrix Initiative, launched by the ILC in 2012 to monitor large land deals, had by March 2020 registered 1,978 concluded or pending land deals affecting over 68 million hectares of land (equivalent to the land area of Kenya and Malawi combined). Almost half of the affected area was formerly owned by communities [61]. This accelerated accumulation of land raises serious concerns about the land rights and food security of marginalized groups such as rural women, the elderly, oppressed castes or ethnic groups, small-scale farmers, and pastoralists $[97,99,100]$.

According to Land Matrix figures accessed in March 2020, a total of 25,249,885 hectares of land in Africa was acquired in large land deals ('land grabs') that are either concluded or intended (those which have failed are excluded from this) [101]. This is a significant $9.3 \%$ of the estimated 271 million hectares of crop land in Africa [1]. This is of particular concern in a continent where the rural population is still rising in total numbers and more than $50 \%$ of people derive their livelihoods from work on farms. Crop land is not the only land affected, but it is the largest proportion of land acquired in these large deals and the comparison indicates how significant these large land deals can be for farming and food production. In Asia there are 11,866,061 hectares of land acquired in large land deals, making up $1.9 \%$ of the 640.5 million hectares of crop land. In Latin America the 9,491,893 hectares acquired in these land deals is approximately $5.7 \%$ of the crop land, while in Eastern Europe the land acquired in large land deals is $18,429,638$ making up approximately $15.2 \%$ of all cropland $[1,101]$. This is a very significant percentage of crop land, perhaps in part due to the sort of practices mentioned above in relation to the abuse of European Union funds for agriculture. With a proportionally smaller rural and farm worker population in Eastern Europe, than for example Africa, this may be relatively less important economically, but it may be problematic in terms of the concentration of political influence it is linked to.

Globally the land acquired in large land deals is primarily existing cropland and high potential forest land; $58 \%$ was cropland and 31\% was operated by small holder farmers prior to the deals [102]. In Africa $36 \%$ of the land acquired by large land deals was formerly smallholder agricultural land and a further $23 \%$ was previously used by larger scale farms. More than half the land acquired is also easily accessible-closer to towns and cities and with them markets-and in more densely populated areas. Only a small proportion, around $10 \%$, of the land affected is arid and marginal land [102]. These land deals are clearly part of a substantially restructuring of farm control and production.

\subsection{The Example of Tanzania}

More details from Tanzania are presented as one example to illustrate some of the trends and dynamics involved. Tanzania was selected due to the availability of data and the lead authors knowledge of the country. Lowder, et al. [103] compared Tanzanian farmland distribution in 1993 (Table 1) and 2013 (Table 2). This is the most recent Living Standards Measurement Study (LSMS) survey, but the indications are that the trends in farm size changes seen here have continued. Notable features of the trends are that there was a large increase in farming households and the area operated and a significant increase in medium and larger size farms that had essentially not existed in Tanzania in 1993. Note that some large state farms would not have been picked up in the LSMS data. Land holding in Tanzania is becoming more unequal, but is relatively equitable compared to the global figures. The proportion of farms smaller than 2 hectares went up from $60.9 \%$ in 1993 to $63.4 \%$ in 2013 and the proportion of land they use dropped from $27.8 \%$ to $22 \%$ (the global figures being $84 \%$ of farms on $12 \%$ of land). Importantly the total number and the proportion of households with the smallest farm sizes, below 1 hectare, increased significantly and their average farm size decreased. This indicates greater pressure on the poorest farmers. The inequality and pressure on land created by the emergence of farms in the 50 to 200 hectare range is of concern, but less significant than the impact 
of large land deals since around 2008, that has seen the creation of mega farms that substantially alter the distribution.

Table 1. Farm land distribution in Tanzania 1993. (Lowder, Bertini, Karfakis and Croppenstedt [103] calculated using LSMS household survey data from the World Bank, plus authors calculation of average farm sizes.).

\begin{tabular}{|c|c|c|c|c|c|}
\hline $\begin{array}{l}\text { Land Sizes in } \\
\text { Hectares (Ha) }\end{array}$ & $\begin{array}{l}\text { Number of Households } \\
\text { (HHs)/Owners }\end{array}$ & $\begin{array}{l}\text { Area Operated } \\
\text { (AO) } \mathrm{Ha}\end{array}$ & Share of HHs & Share AO & Average Size Ha \\
\hline$<1$ & 996,519 & 585,002 & $28.3 \%$ & $7.5 \%$ & 0.59 \\
\hline $1-2$ & $1,148,476$ & $1,596,699$ & $32.6 \%$ & $20.4 \%$ & 1.39 \\
\hline $2-5$ & $1,092,166$ & $3,257,027$ & $31.0 \%$ & $41.5 \%$ & 2.98 \\
\hline 5-10 & 225,369 & $1,476,402$ & $6.4 \%$ & $18.8 \%$ & 6.55 \\
\hline $10-20$ & 53,685 & 714,745 & $1.5 \%$ & $9.1 \%$ & 13.31 \\
\hline $20-50$ & 8,431 & 211,144 & $0.2 \%$ & $2.7 \%$ & 25.04 \\
\hline $50-100$ & 0 & 0 & & & \\
\hline $100-200$ & 0 & 0 & & & \\
\hline$>200$ & 0 & 0 & & & \\
\hline Totals & $3,524,646$ & $7,841,019$ & & $100.0 \%$ & 2.22 \\
\hline
\end{tabular}

Table 2. Farm land distribution in Tanzania 2013. (Lowder, Bertini, Karfakis and Croppenstedt [103] calculated using LSMS household survey data from the World Bank, plus authors calculation of average farm sizes and addition of figures from the Land Matrix 2020).

\begin{tabular}{|c|c|c|c|c|c|}
\hline $\begin{array}{l}\text { Land Sizes in } \\
\text { Hectares (Ha) }\end{array}$ & $\begin{array}{l}\text { Number of Households } \\
\text { (HHs)/Owners }\end{array}$ & $\begin{array}{l}\text { Area Operated } \\
(\mathrm{AO}) \mathrm{Ha}\end{array}$ & Share of HHs & Share AO & Average Size Ha \\
\hline$<1$ & $2,451,115$ & $1,270,104$ & $37.2 \%$ & $7.7 \%$ & 0.52 \\
\hline $1-2$ & $1,730,862$ & $2,380,369$ & $26.3 \%$ & $14.4 \%$ & 1.38 \\
\hline $2-5$ & $1,880,628$ & $5,848,818$ & $28.5 \%$ & $35.3 \%$ & 3.11 \\
\hline 5-10 & 368,973 & $2,503,873$ & $5.6 \%$ & $15.1 \%$ & 6.79 \\
\hline 10-20 & 105,913 & $1,442,112$ & $1.6 \%$ & $8.7 \%$ & 13.62 \\
\hline $20-50$ & 46,584 & $1,260,933$ & $0.7 \%$ & $7.6 \%$ & 27.07 \\
\hline 50-100 & 3,995 & 293,497 & $0.1 \%$ & $1.8 \%$ & 73.47 \\
\hline $100-200$ & 3,781 & 491,928 & $0.1 \%$ & $3.0 \%$ & 130.11 \\
\hline Sub-Totals & $6,591,851$ & $15,491,634$ & & & 2.35 \\
\hline $\begin{array}{l}>200(\text { Land } \\
\text { Matrix) }\end{array}$ & 108 & $1,068,540$ & $0.0 \%$ & $6.5 \%$ & $9,893.89$ \\
\hline $\begin{array}{l}\text { Totals with Land } \\
\text { Matrix data }\end{array}$ & $6,591,959$ & $16,560,174$ & & $100.0 \%$ & 2.51 \\
\hline
\end{tabular}

With the addition of the large land deals, as captured in the Land Matrix data, $6.5 \%$ of the farm land area is now in just 108 land holdings that dwarf all other farm sizes and cover more land than is in the hands of over 2 million of the smallest-scale farmers. These few largest land owners, mostly corporations and investors from outside Tanzania, appear to wield significant influence and attract substantial support. They represent a model that has been vigorously promoted by the Tanzanian government and other rich nations through their "development" agencies and multilateral institutions, not to mention private sector actors. This can be seen most obviously in the Southern Agricultural Growth Corridor of Tanzania (SAGCOT) initiative that was launched with great fanfare by Tanzania's President Jakaya Kikwete at the 2010 World Economic Forum on Africa [104]. The Investment Blueprint published in 2011 spoke of mobilizing US\$3.4 billion over 20 years, with over US\$2 billion of that from private investors [105]. The initiative had an array of powerful supporters, including the World Bank, USAID, Food and Agriculture Organization of the United Nations (FAO), Unilever, Monsanto, Yara, and Syngenta, to name just a few. The SAGCOT plans envisaged using public (including donor) money to leverage corporate investments in farm units of 10,000 hectares or more each, very close to the average land deal size of 9,893 hectares found by the Land Matrix. While SAGCOT has struggled to achieve its ambitious targets, the model it set out to promote seems to be taking hold. 
The contestation in Tanzania is not only over land, but also about control of other resources, such as water, and different approaches to markets, from the belief in the value of existing territorial markets $[106,107]$ to the promotion of "formalization" and visions of commercial farmers linked to larger processors with more focus on exports $[105,108]$. While there are a small number of winners, many small-scale farmers and local communities have lost land and autonomy [104,109] and there have been large-scale and in some cases violent evictions of pastoralists from fertile and water rich land that is being targeted for investors as part of SAGCOT [110].

It is hard to get information on the extent to which market relations have shifted, but what is being promoted could have significant impacts on the millions of small-scale farmers in the country. For example, a FAO sponsored and published analysis of the maize sector gives little attention to the existing food systems supplying most food, including staples like maize [40], and instead suggests that a "small but elite group of maize industry leaders could play a key role in transforming Tanzania's maize value chain." The report goes on to note that "[w]hile some [of these elites] might benefit from guidance on working with smallholder farmers, they could champion and support reorganization of the maize trade" [108], p.18. The report recognizes that the commercialization of the sector it is proposing "will be accompanied by a reduction in the number of active farmers. Equally, formalization of the milling industry will result in small and inefficient millers finding it increasingly difficult to operate under an increasingly competitive environment" [108], p.19. The report doesn't, however, offer any suggestions for how all those displaced from the primary maize production, processing, and distribution should support themselves in the envisaged future.

\subsection{Less Visible Forms of Control over Land and the Value Produced}

Large land deals and related land dispossessions have direct impacts on some of the most vulnerable and they also usher in large-scale farming models and extractive activities that have indirect impacts. Large-scale farms reduce local linkages and generally have less positive impacts on local development when compared to small-scale farming that has greater poverty-reducing effects due to positive impacts from spending and trading in the rural non-farm sector [8,111]. More equitable land-holdings involve many small-scale family farmers who spend more of their income on locally produced goods and services, thus contributing to the local economy $[8,14,111]$. The benefits are generally more and better shared when small-scale farmers operate within territorial markets [6,39]. Small-scale farmers also tend to use more labor per hectare, and per unit of output, than do their larger peers and therefore generate more employment, which is an advantage in low- and middleincome countries with ample available labor. The advantage is often less in high income countries with limited labor availability, but ample capital [6]. Land reforms to create more equitable land holdings can have these beneficial effects, but can also have negative impacts on overall output in some contexts, especially if accompanied by political turmoil and state interventions that create uncertainty and undermine productivity and markets [6,112].

The dynamics of land concentration are not new, but at this time they are happening within an advanced form of corporate capitalism involving investors squeezing whatever they can from the increased production of goods (or "expanded reproduction"). Even the relentless push for greater land and labor productivity, the most direct outcomes of which are higher unemployment and agricultural practices destructive of soils and the environment, is no longer bringing sufficient returns, leading to strategies of "accumulation by dispossession" and the extraction of profit through multiple forms of "rent" (unearned income) captured from land, labor, and other "pseudo commodities" [29,30,113-115]. Greater returns can now be made from capital gains and rents than from investing in actual production $[29,114,116]$, with potentially disastrous implications for employment and food security as such factors no longer align with investors' interests.

Through a process of financialization, agricultural land is becoming an "alternative asset class", with decision-making moving further from farmers and any connection to land and production, as the priority becomes returns to investors and shareholders [117-119]. Farmers have lost power and 
face reduced returns and growing competition for their farmland. The line between food and finance has blurred, and corporate food retailers have also emerged as dominant actors. The politics of the regulation of agricultural derivatives has shifted the global price of food away from the material aspects of supply and demand to become more volatile and more tightly pegged to financial markets $[120,121]$. The number of investment funds operating in the agri-food sector has grown exponentially from 38 in 2005 to 240 in 2014 and 440 in 2018, managing US\$73 billion in assets [122,123]. Pension funds are some of the largest players: by August 2018, 76 public and corporate pension funds had jointly allocated roughly US\$15 billion to farmland investments [124]. Increasingly, development finance, such as World Bank Group loans, is directed through "financial intermediaries" such as commercial banks and equity funds - transactions which are overwhelmingly secret [125]. Financialization exacerbates inequalities and impedes people's collective action due to the highly complex and opaque nature of financial instruments and corporate lobbying power [118].

The incorporation of farmers into contract farming, joint ventures, and value chains are, like financialization, shifting power and value appropriation away from primary producers. Value chain interventions emerged out of the corporate approach to supply chain management [126] and have become ubiquitous in the development sector, with a focus on linking small-scale farmers with "regional and global formal markets" [127], p.3.While some value chain interventions may bring benefits to the farmers involved, the uncritical application of such an approach and the neglect of other options are not justified by the outcomes in many cases $[106,128]$. There is a lack of credible assessments showing that value chains can achieve their intended development goals [129]. Even those promoting value chains have found that they are not effective in reaching the poorest, as they tend to involve farmers who already have more assets and education $[127,129,130]$. Independent studies have found that incorporation into global markets happens on very unequal terms and can have extremely adverse consequences for farmers and workers [80,131-133] and risk undermining the local and territorial markets that most farmers already sell to and where most food is traded $[39,106]$. The core issue is the very unequal power relations involved, which lead to more dependency and inequality, typically transforming peasants into workers on their own land by subordinating them to "the dominant frameworks of global agribusiness and capital accumulation" [134], p.21.

There continues to be a widespread promotion of value chains as a development solution by academics and development practitioners regardless of the lack of evidence of success, especially in meeting the needs of the poorest. This illustrates the influence reflected in Figure 2, with many reports that extol the virtues of value chain interventions, with insufficient evidence, funded by the same institutions that funded the interventions, even if they appear to be by independent researchers. For example, Minten, Randrianarison and Swinnen [130] claim to have shown that "the poorest farmers" in Madagascar benefit from global value chains, but the value chain participants and their sample only involved more privileged farmers in terms of measures such as their education levels, location closer to urban centers, and a higher proportion than typical of male headed households. Their study was funded by well-known value chain promotors including the World Bank and the European Union. In another example the Bill and Melinda Gates Foundation, also keen supporters of value chains and market driven development solutions, "generously" funded a dairy value chain intervention in Bangladesh [135] and then funded the in-depth impact assessment of the project. The researchers concluded with general statements about the positive impact of the project and the potential of such interventions to bring social change, despite the detail of their report showing little evidence of benefits and social change. Among other things they found: there was no significant impact on household nutrition or incomes; women's and girl's workloads increased, while men's and boy's didn't; and men's dominant role as primary decision makers was not affected by program participation [136].

Over the last years there have been a range of initiatives, such as supply chain and banking codes, often pushed by civil society to demand or encourage greater social responsibility in corporate value chains and investment practices, While these voluntary commitments and codes may bring some improvements in specific cases, their limited success in bringing meaningful systemic change has led 
to calls for new forms of joint governance involving corporations, NGOs, and governments, but it remains to be seen if these will be more effective in "social upgrading" $[137,138]$. The indications are that this will not fundamentally shift the power relations and patterns of accumulation. Transnational corporations continue to dominate the governance of global value chains and investments. They spend significant sums of money to lobby and influence states and other institutions, and increasingly exercise global influence, whereas states and civil society tend to focus on particular issues, projects, or geographic areas [139]. The extent of state and civil society influence appears to stay within parameters set by the corporations, or as Davis, Kaplinsky and Morris [139] p.22, put it, they are "successful when it coincides with the interests of the big corporate sector."

The dominant trends are intensifying the exploitation of small-scale farmers and farm workers, who are in a weaker negotiation position, and pushing real wages down, with a steadily increasing share of value, including that from improved productivity, going to capital and less going to labor $[113,140,141]$.

\subsection{Elite and Corporate Policy Influence}

The interests of land owners and of corporations operating in other parts of the agri-food sector are systematically over-represented in policy making processes and are often hard to separate from the interests of government elites. A good example is the "bancada ruralista" (Parliamentary Agricultural Front) in Brazil, which represents the agri-industrial sector in the National Congress. In South Africa, the Agricultural Business Council, known as Agbiz, performs a similar role representing the biggest corporations in the agriculture and food sector, including banks and international seed companies. Agbiz are proud to state on their web site that: "Through its direct participation, Agbiz is able to influence policy makers at the highest level" [142]. When the South African President convened an Advisory Panel on Land Reform and Agriculture in 2018, Agbiz had their chief economist on the panel. AgriSA - a federation that represents the largest farmers, land owners and commodity organizations - also had their President on the panel. Farm workers and landless people were among those not represented. Unsurprisingly, this Advisory Panel failed to agree on a vision and key actions for the transformation of South Africa's highly unequal land holding regime. In these and most other countries, the landless and land-poor barely have a political voice, leaving their needs largely ignored in policies and budgets. This is a failure of democracy and it ensures that redistributive policies are not on the agenda unless there are political representatives or social movements able to drive them [143].

Most states are engaged in a "race to the bottom" to try and attract investors by pandering to the demands of corporations and elites, while neglecting the rights and needs of the majority [144,145]. Policy measures include deregulating land markets, creating special economic development zones where national rules don't apply, relaxing environmental protection, granting tax breaks to corporations, suppressing union organizing, and closing space for social resistance [93,144,146-149].

National security policies are commonly used to repress social movement and civil society resistance to the extractivist agenda. Land and human rights defenders, especially indigenous people, are increasingly attacked and killed with women suffering particular forms of sexual violence [93]. Impunity is a common feature of this violence, with arrests made in only $12 \%$ of the cases of the murder of land and human rights defenders in 2017 [150]. The legal system and judicial harassment is also used to criminalize activism and to intimidate and silence human rights and environmental defenders. Activists are forced to devote time and finances to legal defense and the stigma of association with crime alienates them from support networks [64].

International development institutions have also been actively shaping conditions to make land investments more attractive. The World Bank, despite claiming to secure farmers' access to land, has been accused of undermining land rights and increasing land inequality by financing large-scale investments, promoting contract marketing schemes, and discouraging regulation through its ease of doing business rankings [148,151]. Agricultural "growth corridors", such as the SAGCOT example in Tanzania, have become one of the prominent vehicles for the World Bank, corporations, 
and development agencies to apply a range of measures in support of corporate investments and accumulation, often at the expense of local farmers and businesses [104,134,147-149,152].

International investment treaties and free trade agreements shield the interests of investors over other considerations, weakening national capacity to regulate food, land, and water sectors and discouraging redistributive reforms [153-156]. For example, in 2017 a Swedish company filed a US\$500 million claim against the Government of Tanzania at the International Centre for Settlement of Investment Disputes (ICSID) housed at the World Bank, concerning the cancellation of an investment deal involving 20,000 hectares of land and the potential eviction of 1500 local farming families [157-159].

Some states are also handing over public land (including forests and communal land) to private companies for tourism, mining, and large-scale commercial agriculture [29,61]. Land dispossession in the name of conservation - but often actually for tourism or other businesses-has gone on historically and continues today with large-scale evictions, especially of Indigenous people $[110,160,161]$. This is happening despite evidence that Indigenous peoples with rights to their territories and appropriate policies are the best defenders of the environment and biodiversity [42,162,163].

\subsection{Responses from Below}

The worsening terms of trade for farmers in traditional agricultural commodities is leading to a range of responses on the ground. These include strategies by rural people to draw on a diversity of income sources to sustain their livelihoods, such as seen in the emergence of multifunctional agriculture and different configurations of rural livelihoods. There is a growth, for example, of new activities, such as agri-tourism, environmental services, and care services on farms in the Netherlands [164]. Peasant farmers in the Amazon region now rely as much on remittances and wild or semi wild non-timber forest produce as on traditional grain crops [26]. Niche or nested markets, often based on local and regional identity and specialization, are creating new economic opportunities [165,166].

The addition of new sources of livelihoods and new on farm activities often complements agricultural production. In many cases it has led to increased land use [164] and other benefits, such as a surprising (in the face of a dominant deforestation narrative) expansion of forest cover on peasant held land in parts of the Amazon region [26].

Even in settings where rural livelihoods are increasingly dependent on outside sources of income, such as wages, remittances and pensions, the role of land and the rural homestead is changing, but is not necessarily diminished. Hebinck, et al. [167], for example, find in the rural Eastern Cape of South Africa, that while crop production has declined, there is a shift into more grazing and the rural homestead serves an important social function as a place for family gatherings, rituals, and worship of ancestors alongside growing some food and rearing livestock. Land inequality remains important as the emergence of these new configurations and who they serve depends on the equality of land access and rights involved.

It is perhaps in these changes on the ground and the everyday practices as well as struggles of the subaltern that solutions to land inequality and its negative outcomes can be found. These include the food sovereignty movement, agro-ecology (in its radical forms), indigenous people's economics, territorial markets, symbiotic food systems, and solidarity economy alternatives [38,39,168-172]. Central to these solutions are ways of organizing production and distribution that build greater autonomy from corporate systems and focus less on maximizing production, instead giving more attention to what works for people, environment, and society.

\section{Conclusions}

There is currently a great lack of data available to properly show the dynamics and impacts of these land inequality trends. While there is some information on farm sizes it is not gathered regularly and consistently across all countries and there is even less comparable data on the nature of rights to the land. The SDG commitments to monitor indicators 1.4.2, 5.a.1 and 5.a.2, which would at least provide a breakdown of secure land rights by sex, are still largely unimplemented. We have even less 
data on the changing nature of control over financing of agriculture and on the appropriation of value in the marketing of produce, as well as challenges in linking such data to information on land parcel sizes and rights. There is a need for governments and others to regularly gather more common and consistent primary data, at a minimum this would include what is suggested by the World Program for the Census of Agriculture [173,174] and that agreed in relation to SDG monitoring [175-177]. Further studies could draw on such data to investigate and analyze land inequality in all its dimensions. More country and local case studies that go into greater depth would also be useful and achievable in the short-term.

It seems clear, however, that there is a dominant process creating increasingly untenable levels of land inequality with greater land concentration in fewer hands, while the majority who depend on land for their livelihoods struggle to survive on smaller parcels of land and deal with worsening terms of trade. Even in contexts of less dependence on land, high levels of land inequality are impacting negatively on democracy, social cohesion, and the environment.

There are counter movements to the dominant trends, such as people in their every-day practices reconfiguring their economic lives and land uses, social movements resisting commoditization, peasant movements pushing for food sovereignty, and civil society groups advocating for more responsible business practices. Reinforcing these movements seems important, as is further study of their impacts, in particular to analyze if they are bringing systemic or only limited reforms. Interventions need to avoid reinforcing the status quo driving inequality and instead address the structural drivers of land inequality for meaningful and sustainable change.

Historically, land reforms were seen as time bound and put in place to deal with specific injustices, such as colonial land dispossession, after particular national political moments, such as liberation of a country from colonialism. We can see now that land reforms are needed as an ongoing processes to reduce and deal with the negative outcomes of what are increasingly global economic processes. Land redistribution policies and programs-including direct interventions to acquire land, progressive property and inheritance tax reforms, etc.-are needed as much as ever. To be successful, these need to be combined with interventions—-such as democratizing control of markets and capital—to create greater autonomy and equality in the wider agri-food system and in the new ways people are configuring rural life.

Karl Polanyi's identification of 'labor, land, and money' as fictitious commodities and his related critique of the utopian myth of the self-regulating market economy is useful to analyzing and addressing land inequality [115]. Although essential to production, labor, land, and money are not produced for sale in the market and therefore do not respond to market forces as commodities are expected to. People are not produced in response to market demand. Land and nature is not produced for sale [115]. Finding new ways to manage these three factors of production, outside the paradigm of their maximum exploitation, remains central to a systemic response.

Author Contributions: Conceptualization, M.C.A.W. and A.G.; methodology, M.C.A.W. and A.G.; investigation, M.C.A.W. and A.G.; formal analysis, M.C.A.W. and A.G.; writing-original draft preparation, Marc Wegerif.; writing-review and editing, M.C.A.W. and A.G.; visualization; M.C.A.W. and A.G.; funding acquisition, M.C.A.W. and A.G. All authors have read and agree to the published version of the manuscript.

Funding: The research was funded by the International Land Coalition (https://www.landcoalition.org), grant number 69345-0001.

Acknowledgments: We thank Giulia Baldinelli and Ward Anseeuw of the International Land Coalition for their support and suggestions. We also appreciated the contributions from participants in an International Land Coalition convened workshop on land and inequality that took place in Rome in March 2019. We appreciate the contributions of the anonymous external reviewers who gave tough feedback on the first draft submitted.

Conflicts of Interest: The authors declare no conflict of interest. The funders had no role in the design of the study; in the collection, analyses, or interpretation of data; in the writing of the manuscript, or in the decision to publish the results. 


\section{References}

1. FAO. World Food and Agriculture Statistical Pocketbook 2019; Food and Agriculture Organization of the United Nations: Rome, Italy, 2019.

2. Losch, B.; Fréguin-Gresh, S.; White, É.T. Structural dimensions of liberalization on agriculture and rural development: A cross-regional analysis on rural change. In Synthesis Report of the Ruralstruc Program; Cirad, World Bank, French Ministry of Foreign Affairs: Paris, France; Washington, DC, USA, 2010.

3. FAO. The State of Food and Agriculture: Climate Change, Agriculture and Food Security; Food and Agriculture Organization of the United Nations: Rome, Italy, 2016.

4. Meinzen-Dick, R.; Quisumbing, A.; Doss, C.; Theis, S. Women's land rights as a pathway to poverty reduction: Framework and review of available evidence. Agric. Syst. 2019, 172, 72-82. [CrossRef]

5. Global Hunger Index. Global Hunger Index 2019: The Challenge of Hunger and Climate Change; Helvetas: Dublin, Ireland; Bonn, Germany, 2019; Volume 2019.

6. Lipton, M.; Saghai, Y. Food security, farmland access ethics, and land reform. Glob. Food Secur. 2017, 12, 59-66. [CrossRef]

7. FAO. The State of Food and Agriculture: Leveraging Food Systems for Inclusive Rural Transformation; Food and Agriculture Organization of the United Nations: Rome, Italy, 2017.

8. Mellor, J.W.; Malik, S.J. The Impact of Growth in Small Commercial Farm Productivity on Rural Poverty Reduction. World Dev. 2017, 91,1-10. [CrossRef]

9. FAO. The State of Food and Agriculture 2010-2011: Women in Agriculture: Closing the Gender Gap for Development; Food and Agriculture Organization of the United Nations: Rome, Italy, 2011.

10. Meinzen-Dick, R. Property Rights for Poverty Reduction? In DESA Working Paper No. 91, December 2009; United Nations Department of Economic and Social Affairs: New York, NY, USA, 2009.

11. Deininger, K.W. Land Policies for Growth and Poverty Reduction; World Bank: Washington, DC, USA, 2003.

12. Carter, M.R. Land Ownership Inequality and the Income Distribution Consequences of Economic Growth; UNU/WIDER: Helsinki, Finland, 2000.

13. ECLAC. The Social Inequality Matrix in Latin America; Economic Commission for Latin America and the Caribbean: Santiago, Chile, 2016.

14. Binswanger-Mkhize, H.P.; Bourguignon, C.; van den Brink, R. Agricultural Land Redistribution: Towards Greater Consensus on the How; The World Bank: Washington, DC, USA, 2009.

15. Deininger, K.; Squire, L. New ways of looking at old issues: Inequality and growth. J. Dev. Econ. 1998, 57, 259-287. [CrossRef]

16. Sokoloff, K.L.; Engerman, S.L. Institutions, factor endowments, and paths of development in the new world. J. Econ. Perspect. 2000, 14, 217-232. [CrossRef]

17. Galor, O.; Moav, O.; Vollrath, D. Inequality in landownership, the emergence of human-capital promoting institutions, and the great divergence. Rev. Econ. Stud. 2009, 76, 143-179. [CrossRef]

18. Lipton, M. Land Reform in Developing Countries: Property Rights and Property Wrongs; Routledge: London, UK; New York, NY, USA, 2009.

19. Prosterman, R.L.; Riedinger, J.M. Land Reform and Democratic Development; Johns Hopkins University Press: Baltimore, MD, USA, 1987.

20. UN ESC. Report of the Inter-Agency and Expert Group on Sustainable Development Goal Indicators. In Statistical Commission Forty-Seventh Session; E/CN.3/2016/2/Rev.1; United Nations: New York, NY, USA, 2016.

21. CEDAW. General recommendation No. 34 on the rights of rural women. In CEDAW/C/GC/34; United Nations: New York, NY, USA, 2016.

22. CFS. Voluntary Guidelines on the Responsible Governance of Tenure of Land, Fisheries and Forests in the Context of National Food Security; Food and Agriculture Organization of the United Nations: Rome, Italy, 2012.

23. African Union. Land Policy in Africa: A Framework to Strengthen Land Rights, Enhance Productivity and Secure Livelihoods; African Union and Economic Commission for Africa: Addis Ababa, Ethiopia, 2009.

24. African Union. Declaration on land issues and challenges in Africa. In Assembly/AU/Decl.1(XIII) Rev.1; AU Commission: Addis Ababa, Ethiopia, 2009.

25. Ramírez-Miranda, C. Critical reflections on the New Rurality and the rural territorial development approaches in Latin America. Agron. Colomb. 2014, 32, 122-129. [CrossRef] 
26. Hecht, S. The new rurality: Globalization, peasants and the paradoxes of landscapes. Land Use Policy 2010, 27, 161-169. [CrossRef]

27. Hebinck, P. De-/re-agrarianisation: Global perspectives. J. Rural. Stud. 2018, 61, 227-235. [CrossRef]

28. Black, C. Maturing Australia through Australian aboriginal narrative law. South Atl. Q. 2011, 110, 347-362. [CrossRef]

29. Andreucci, D.; García-Lamarca, M.; Wedekind, J.; Swyngedouw, E. Value grabbing: A political ecology of rent. Capital. Nat. Soc. 2017, 28, 1-20. [CrossRef]

30. Harvey, D. The New Imperialism: Accumulation by Dispossession. Soc. Regist. 2004, 40, 63-87.

31. Bartlett, K.T. Feminism and Economic Inequality. Law Inequal. J. Theory Pract. 2017, 35, 265-287.

32. Kabeer, N. Leaving no one behind: The challenge of intersecting inequalities. In World Social Sciences Report, 2016, Challenging Inequalities: Pathways to a Just World; ISSC, IDS, UNESCO, Eds.; UNESCO Publishing: Paris, France, 2016.

33. Stewart, F. Horizontal Inequalities: A Neglected Dimension of Development; Working Paper Series; Queen Elizabeth House, University of Oxford: Oxford, UK, 2002.

34. Brown, M.T. Latin American Inequalities and Reparations. In The Social Life of Economic Inequalities in Contemporary Latin America; Ystanes, M., Strønen, I.Å., Eds.; Springer: Cham, Switzerland, 2018; pp. $253-272$.

35. GRAIN. The Global Farmland Grab in 2016: How Big, How Bad? GRAIN: Barcelona, Spain, 2016.

36. Knight, R.; Adoko, J.; Siakor, A.; Salomao, A.; Auma, T.; Kaba, A.; Tankar, I. Protecting Community Lands and Resources: Evidence from Liberia, Mozambique and Uganda; Namati and International Development Law Organization (IDLO): Rome, Italy, 2012.

37. Anseeuw, W.; Wily, L.A.; Cotula, L.; Taylor, M. Land Rights and the Rush for Land: Findings from the Global Commercial Pressures on Land Research Project, 9789295093751; ILC: Rome, Italy, 2012.

38. Wegerif, M.C.A. An ethnographic exploration of food and the city. Anthropol. Today 2018, 34, 16-19. [CrossRef]

39. CSM. Connecting Smallholders to Markets: An Analytical Guide. In International Civil Society Mechanism, Hands On the Land Alliance for Food Sovereignty; Civil Society Mechanism, World Committee on Food Security: Rome, Italy, 2016; Volume 12.

40. Wegerif, M.C.; Wiskerke, J.S. Exploring the Staple Foodscape of Dar es Salaam. Sustainability 2017, 9, 1081. [CrossRef]

41. RRI. Who owns the World's land? A Global Baseline of Formally Recognized Indigenous and Community Land Rights; Rights and Resources Initiative: Washington, DC, USA, 2015.

42. Pearce, F. Common Ground: Securing Land Rights and Safeguarding the Earth; Oxfam, International Land Coalition, Rights and Resources Initiative, Ed.; Oxfam: Oxford, UK, 2016.

43. Giovarelli, R.; Richardson, A.; Scalise, E. Gender E Collectively Held Land: Good Practices E Lessons Learned from Six Global Case Studies; Landesa and Resource Equity: Seattle, WA, USA, 2016.

44. Knight, R.; Brinkhurst, M.; Vogelsang, J.; Namati's Community Land Protection partner organizations. Community Land Protection Facilitators Guide; Namati Innovations in Legal Empowerment: Washington, DC, USA, 2017.

45. Larson, A.M.; Springer, J. Recognition and respect for tenure rights. In NRGF Conceptual Paper; IUCN, CEESP and CIFOR: Gland, Switzerland, 2016.

46. Cronkleton, P.; Larson, A. Formalization and collective appropriation of space on forest frontiers: Comparing communal and individual property systems in the Peruvian and Ecuadoran Amazon. Soc. Nat. Resour. 2015, 28, 496-512. [CrossRef]

47. EGM on CSW 62. Report of the Expert Group Meeting on the CSW 62 Priority Theme: Challenges and Opportunities in Achieving Gender Equality and the Empowerment of Rural Women and Girls; UN Women: Rome, Italy, 2017.

48. Budlender, D.; Moussié, R. Making Care Visible: Women's Unpaid Care Work in Nepal, Nigeria, Uganda and Kenya; ActionAid: Johannesburg, South Africa, 2013.

49. Wegerif, M.C. Feeding Dar es Salaam: A Symbiotic Food System Perspective; Wageningen University: Wageningen, The Netherlands, 2017.

50. Guereña, A.; Wegerif, M.C.A. Framing Document on Land Inequality; ILC initiative International Land Coalition: Rome, Italy, 2019. 
51. DRDLR. Land Audit Report: Phase Ii: Private Land Ownership By Race, Gender And Nationality. In November 2017, Version 2; Department of Rural Development and Land Reform: Pretoria, South Africa, 2017.

52. Lowder, S.K.; Skoet, J.; Raney, T. The number, size, and distribution of farms, smallholder farms, and family farms worldwide. World Dev. 2016, 87, 16-29. [CrossRef]

53. Grain. Hungry for Land: Small Farmers Feed the World with Less than a Quarter of all Farmland; Grain: Barcelona, Spain, 2014.

54. FAO. Agricultural Land (sq. km). Available online: https://data.worldbank.org/indicator/AG.LND.AGRI.K2 (accessed on 20 February 2019).

55. Lowder, S.K.; Skoet, J.; Singh, S. What do we really know about the number and distribution of farms and family farms in the world? In Background Paper for the State of Food and Agriculture 2014; ESA Working Paper No. 14-02; Food and Agriculture Organisation of the United Nations: Rome, Italy, 2014.

56. EC. Farm Structures; European Union, DG Agriculture and Rural Development: Brussels, Belgium, 2018.

57. Jayne, T.S.; Chamberlin, J.; Traub, L.; Sitko, N.; Muyanga, M.; Yeboah, F.K.; Anseeuw, W.; Chapoto, A.; Wineman, A.; Nkonde, C. Africa's changing farm size distribution patterns: The rise of medium-scale farms. Agric. Econ. 2016, 47, 197-214. [CrossRef]

58. Eurostat. Farm structure statistics. In Eurostat: Statistics Explained; Eurostat: Basel, Switzerland, 2015.

59. Kay, S. Land grabbing and land concentration in Europe. Res. Brief. Amst. Transnatl. Inst. 2016. Available online: https://www.tni.org/en/publication/land-grabbing-and-land-concentration-in-europe (accessed on 27 March 2020).

60. De Schutter, O. We Want Peasants; Land Portal: 2018. Available online: https://landportal.org/blog-post/2018/ 09/we-want-peasants (accessed on 27 March 2020).

61. Nolte, K.; Chamberlain, W.; Giger, M. International Land Deals for Agriculture: Fresh Insights from the Land Matrix: Analytical Report II; Centre for Development and Environment (CDE), Centre de coopération internationale en recherche agronomique pour le développement (CIRAD), German Institute of Global and Area Studies (GIGA), University of Pretoria, Bern Open Publishing (BOP): Pretoria, South Africa, 2016.

62. Guereña, A. A Snapshot of Inequality: What the Latest Agricultural Census Reveals about Land Distribution in Colombia; Oxfam: Oxford, UK, 2017.

63. FAO. Number and Area of Holdings, and Gini's Index of Concentration: 1990 Round of Agricultural Censuses. Available online: http://www.fao.org/economic/the-statistics-division-ess/world-census-ofagriculture/additional-international-comparison-tables-including-gini-coefficients/table-1-number-andarea-of-holdings-and-ginis-index-of-concentration-1990-round-of-agricultural-censuses/en/ (accessed on 19 February 2019).

64. Guereña, A. Unearthed: Land, Power, and Inequality in Latin America; Oxfam: Oxford, UK, 2016.

65. Land Matrix. Available online: https://landmatrix.org (accessed on 27 March 2020).

66. Gebrekidan, S.; Apuzzo, M.; Novak, B. The Money Farmers: How Oligarchs and Populists Milk the E.U. for Millions. Available online: https://www.nytimes.com/2019/11/03/world/europe/eu-farm-subsidy-hungary. html (accessed on 12 March 2019).

67. Asiama, K.; Bennett, R.; Zevenbergen, J. Land consolidation on Ghana's rural customary lands: Drawing from The Dutch, Lithuanian and Rwandan experiences. J. Rural. Stud. 2017, 56, 87-99. [CrossRef]

68. Demetriou, D.; Stillwell, J.; See, L. A new methodology for measuring land fragmentation. Comput. Environ. Urban Syst. 2013, 39, 71-80. [CrossRef]

69. Van Dijk, T. Dealing with Central European Land Fragmentation; Eburon: Delft, The Netherlands, 2003.

70. Doss, C.R.; Kovarik, C.; Peterman, A.; Quisumbing, A.; van den Bold, M. Gender Inequalities in Ownership and Control of Land in Africa: Myths versus Reality; IFPRI: Washington, DC, USA, 2013. [CrossRef]

71. FAO. Gender and Land Rights. In Economic and Social Perspectives; FAO: Rome, Italy, 2010; Volume 2015, p. 8.

72. Deere, C.D.; León, M. The gender asset gap: Land in Latin America. World Dev. 2003, 31, 925-947. [CrossRef]

73. Kelsey, J.-C.; Dick, L.; Bizoza, A. The Gendered Nature of Land and Property Rights in Post-Reform Rwanda; USAID|LAND Project: Kigali, Rwanda, 2014.

74. UN Women. Progress of the World's Women 2015-2016: Transforming Economies, Realizing Rights; United Nations Women: New York, NY, USA, 2015.

75. FAO. Governing Land for Women and Men: A Technical Guide to Support the Achievement of Responsible Gender-Equitable Governance of Land Tenure; Food and Agriculture Organisation: Rome, Italy, 2013. 
76. Deere, C.D.; León, M. Género, Propiedad y Empoderamiento: Tierra, Estado y Mercado en América Latina; Universidad Nacional de Colombia: Bogotá, Colombia, 2000.

77. FAO. Gender and Land Rights Database: Gender and Land Statistics. Available online: http://www.fao.org/ gender-landrights-database/data-map/statistics/en/ (accessed on 19 January 2019).

78. Ledger, T. An Empty Plate: Why We Are Losing the Battle for Our Food System, Why It Matters, and How We Can Win It Back; Jacana Media: Johannesburg, South Africa, 2016.

79. Wegerif, M.; Russell, B.; Grundling, I. Still Searching for Security: The Reality of Farm Dweller Evictions in South Africa; Nkuzi Development Association: Polokwane, South Africa, 2005.

80. Du Toit, A. Forgotten by the highway: Globalisation, adverse incorporation and chronic poverty in a commercial farming district of South Africa. Chronic Poverty Dev. Policy 2004. [CrossRef]

81. Jayne, T.S.; Yamano, T.; Weber, M.T.; Tschirley, D.; Benfica, R.; Chapoto, A.; Zulu, B. Smallholder income and land distribution in Africa: Implications for poverty reduction strategies. Food Policy 2003, 28, 253-275. [CrossRef]

82. FAO; UN-Habitat. On Solid Ground: Addressing Land Tenure Issues after Natural Disasters; Food and Agriculture Organization of the United Nations: Rome, Italy, 2010.

83. Stiglitz, J.E. The Price of Inequality: How Today's Divided Society Endangers Our Future; WW Norton \& Company: New York, NY, USA, 2012.

84. Giridharadas, A. Winners Take All: The Elite Charade of Changing the World; Alfred, A., Ed.; Knopf: New York, NY, USA, 2018.

85. Pimentel, D.A.V.; Aymar, I.M.; Lawson, M. Reward Work, Not Wealth; Oxfam: Oxford, UK, 2018.

86. McKinley, D.T. South Africa's Corporatised Liberation: A Critical Analysis of the ANC in Power; Jacana: Johannesburg, South Africa, 2017.

87. Mamdani, M. Citizen and Subject: Contemporary Africa and the Legacy of Late Colonialism; Princeton University Press: Princeton, NJ, USA, 1996; p. 353.

88. Rodney, W. How Europe Underdeveloped Africa; Bogle-L'Ouverture Publications: London, UK, 1972.

89. Frankema, E. The colonial roots of land inequality: Geography, factor endowments, or institutions? Econ. Hist. Rev. 2010, 63, 418-451. [CrossRef]

90. Brockett, C.D. Measuring political violence and land inequality in Central America. Am. Political Sci. Rev. 1992, 86, 169-176. [CrossRef]

91. Bond, P.; Garcia, A.; Garcia, A. Elite Transition-Revised and Expanded Edition: From Apartheid to Neoliberalism in South Africa; Pluto Press: London, UK, 2014.

92. Griffiths, T. Indigenous peoples, land tenure and land policy in Latin America. In Land Reform, Land Settlement and Cooperatives; FAO, Ed.; Food and Agrciulture Organization of the United Nations: Rome, Italy, 2004; Volume 1, pp. 46-63.

93. Global Witness. At What Cost? Irresponsible Business and the Murder of Land and Environmental Defenders in 2017; Global Witness: London, UK, 2018.

94. Deininger, K.; Byerlee, D. Rising Global Interest in Farmland: Can It Yield Sustainable and Equitable Benefits? The World Bank: Washington, DC, USA, 2011.

95. Alexandratos, N.; Bruinsma, J. World Agriculture Towards 2030/2050: The 2012 Revision; ESA Working Paper No. 12-03; Agricultural Development Economics Division, Food and Agricultural Organization of the United Nations: Rome, Italy, 2012.

96. Corley, R. How much palm oil do we need? Environ. Sci. Policy 2009, 12, 134-139. [CrossRef]

97. De Schutter, O. How not to think of land-grabbing: Three critiques of large-scale investments in farmland. J. Peasant. Stud. 2011, 38, 249-279. [CrossRef]

98. Merlet, M. Agricultura y Alimentación en Cuestión: Las tierras cultivables no cultivadas en el mundo. In Las Notes de la C2A; AGTER: Nogent-sur-Marne, France, 2013.

99. Cotula, L. Land Grab or Development Opportunity? Agricultural Investment and International Land Deals in Africa; Iied: London, UK, 2009.

100. Borras, S.M., Jr.; Franco, J.C.; Kay, C.; Spoor, M. Land grabbing in Latin America and the Caribbean, viewed from a broader international perspective. In The Land Market in Latin America and the Caribbean: Concentration and Foreignization; Gómez, S., Ed.; Food and Agriculture Organzation of the United Nations: Santiago, Chile, 2014; p. 21.

101. Land Matrix. Available online: https://landmatrix.org/global/ (accessed on 12 March 2020). 
102. Nolte, K.; Chamberlain, W.; Giger, M. International Land Deals for Agriculture. Fresh insights from the Land Matrix: Analytical Report II; Centre for Development and Environment, University of Bern, Centre de coopération internationale en recherche agronomique pour le développement; German Institute of Global and Area Studies, University of Pretoria, Bern Open Publishing: Bern, Switzerland; Montpelier, VT, USA; Hamburg, Germany; Pretoria, South Africa, 2016.

103. Lowder, S.K.; Bertini, R.; Karfakis, P.; Croppenstedt, A. Transformation in the size and distribution of farmland operated by household and other farms in select countries of sub-Saharan Africa. In Proceedings of the 5th International Conference of the African Association of Agricultural Economists, Addis Ababa, Ethiopia, 23-26 September 2016.

104. Sulle, E.; Hall, R. Reframing the New Alliance Agenda: A Critical Assessment Based on Insights from Tanzania; Future Agricultures. 2013. Available online: https://www.future-agricultures.org/publications/policy-briefsdocument/reframing-the-new-alliance-agenda-a-critical-assessment-based-on-insights-from-tanzania/ (accessed on 27 March 2020).

105. SAGCOT. Southern Agricultural Growth Corridor of Tanzania: Investment Blue Print; AgDevCo, Prorustica, Eds.; SAGCOT: Dar es Salaam, Tanzania, 2011.

106. Wegerif, M.C.A.; Martucci, R. Milk and the city: Raw milk challenging the value claims of value chains. Agroecol. Sustain. Food Syst. 2019, 42. [CrossRef]

107. Wegerif, M.C.A.; Hebinck, P. The Symbiotic Food System: An Alternative'Agri-Food System Already Working at Scale. Agriculture 2016, 6, 40. [CrossRef]

108. Wilson, R.T.; Lewis, J. The Maize Value Chain in Tanzania: A Report from the Southern Highlands Food Systems Programme; Food and Agriculure Organization of the United Nations: Rome, Italy, 2015.

109. Chachage, C.; Baha, B. Accumulation by Land Dispossession and Labour Devaluation in Tanzania: The Case of Biofuel and Forestry Investments in Kilwa and Kilolo; Land Rights Research and Resources Institute (LARRRI/HAKIARDHI) and Oxfam: Dar es Salaam, Tanzania, 2010.

110. PINGO's Forum. Eviction of Pastoralists from Kilombero and Rufiji Valleys, Tanzania; PINGO's Forum: Arusha, Tanzania, 2013.

111. Mellor, J.W. Pro-Poor Growth: The Relation between Growth in Agriculture and Poverty Reduction. Prepared for USAID/G/EGAD. 1999. Available online: http://agronor.org/Mellor1.htm (accessed on 12 February 2019).

112. Adamopoulos, T.; Restuccia, D. Land Reform and Productivity: A Quantitative Analysis with Micro Data; 0898-2937; National Bureau of Economic Research: Cambridge, MA, USA, 2019.

113. Lannen, A.; Bieri, S.; Bader, C. Inequality: What's in a word? In CDE Policy Brief, No. 14; CDE: Bern, Switzerland, 2019.

114. Harvey, D. The enigma of capital and the crisis this time. In Proceedings of the American Sociological Association Meetings, Atlanta, GA, USA, 16 August 2010.

115. Polanyi, K. The Great Transformation: The Political and Economic Origins of Our Time; Beacon Press: Boston, MA, USA, 1957.

116. Piketty, T. Capital in the 21st Century; Harvard University: Cambridge, MA, USA, 2014.

117. Ducastel, A.; Anseeuw, W. Facing financialization: The divergent mutations of agricultural cooperatives in postapartheid South Africa. J. Agrar. Chang. 2018, 18, 555-570. [CrossRef]

118. Clapp, J.; Isakson, S.R. Speculative Harvests: Financialization, Food, and Agriculture; Practical Action: Rugby, UK, 2018.

119. Ducastel, A.; Anseeuw, W. Agriculture as an asset class: Reshaping the South African farming sector. Agric. Hum. Values 2017, 34, 199-209. [CrossRef]

120. Isakson, S.R. Food and finance: The financial transformation of agro-food supply chains. J. Peasant. Stud. 2014, 41, 749-775. [CrossRef]

121. Clapp, J.; Helleiner, E. Troubled futures? The global food crisis and the politics of agricultural derivatives regulation. Rev. Int. Political Econ. 2012, 19, 181-207. [CrossRef]

122. Valoral Advisors. 2018 Global Food E Agriculture Investment Outlook: Investing Profitably Whilst Fostering a Better Agriculture; Valoral Advisors: Luxembourg, 2018.

123. Valoral Advisors. 2015 Global Food E Agriculture Investment Outlook: Institutional Investors Meet Farmers; Valoral Advisors: Luxembourg, 2015. 
124. GRAIN. The Global Farmland Grab by Pension Funds Needs to Stop; GRAIN. 2018. Available online: https: //www.grain.org/en/article/6059-the-global-farmland-grab-by-pension-funds-needs-to-stop (accessed on 27 March 2020).

125. BankTrack. About BankTrack. Available online: https://www.banktrack.org (accessed on 3 December 2019).

126. Gereffi, G.; Humphrey, J.; Kaplinsky, R. Introduction: Globalisation, value chains and development. IDS Bull. 2001, 32, 1-8. [CrossRef]

127. Seville, D.; Buxton, A.; Vorley, B. Under What Conditions are Value Chains Effective Tools for Pro-Poor Development. Available online: http://pubs.iied.org/16029IIED.html (accessed on 21 August 2011).

128. Tapela, B.N. Livelihoods in the wake of agricultural commercialisation in South Africa's poverty nodes: Insights from small-scale irrigation schemes in Limpopo Province. Dev. S. Afr. 2008, 25, 181-198. [CrossRef]

129. Humphrey, J.; Navas-Alemán, L. Value Chains, Donor Interventions and Poverty Reduction: A Review of Donor Practice; 2040-0217; Institute of Development Studies: Brighton, UK, 2010; pp. 1-106.

130. Minten, B.; Randrianarison, L.; Swinnen, J.F.M. Global retail chains and poor farmers: Evidence from Madagascar. World Dev. 2009, 37, 1728-1741. [CrossRef]

131. Chamberlain, W.; Anseeuw, W. Inclusive businesses and land Reform: Corporatization or transformation? Land 2018, 7, 18. [CrossRef]

132. Burgos, S.; Guereña, A. Land inequality and power in Latin America. In Proceedings of the Land and Poverty, Washington, DC, USA, 20-24 March 2016.

133. Hickey, S.; Du Toit, A. Adverse Incorporation, Social Exclusion, and Chronic Poverty. In Chronic Poverty: Concepts, Causes and Policy; Sheperd, A., Brunt, J., Eds.; Palgrave Macmillan: London, UK, 2013; pp. 134-159.

134. Amanor, K.S.; Chichava, S. South-south cooperation, agribusiness, and African agricultural development: Brazil and China in Ghana and Mozambique. World Dev. 2016, 81, 13-23. [CrossRef]

135. Care. Sustainable Dairy Value Chains; Care: Geneva, Switzerland, 2015; Volume 2018.

136. Quisumbing, A.; Roy, S.; Njuki, J.; Tanvin, K.; Waithanji, E. Can dairy value-chain projects change gender norms in rural Bangladesh? In Impacts on Assets, Gender Norms, and Time Use; IFPRI \& ILRI: Washington, DC, USA, 2013.

137. Barrientos, S.; Knorringa, P.; Evers, B.; Visser, M.; Opondo, M. Shifting regional dynamics of global value chains: Implications for economic and social upgrading in African horticulture. Environ. Plan. A Econ. Space 2016, 48, 1266-1283. [CrossRef]

138. Lee, J.; Gereffi, G. Global value chains, rising power firms and economic and social upgrading. Crit. Perspect. Int. Bus. 2015, 11, 319-339. [CrossRef]

139. Davis, D.; Kaplinsky, R.; Morris, M. Rents, power and governance in global value chains. J. World Syst. Res. 2018, 24, 43-71. [CrossRef]

140. Cochet, H. Capital-labour separation and unequal value-added distribution: Repositioning land grabbing in the general movement of contemporary agricultural transformations. J. Peasant. Stud. 2018, 45, 1410-1431. [CrossRef]

141. Cochet, H.; Merlet, M. Land grabbing and share of the value added in agricultural processes. A new look at the distribution of land revenues. In Proceedings of the International Academic Conference Global Land Grabbing, Brighton, UK, 6-8 April 2011.

142. Agbiz. Legislation. Available online: https://agbiz.co.za/legislation/sa-s-legislation-process (accessed on 3 December 2019).

143. Oxfam Brasil. Terrenos da Desigualdade: Terra, Agricultura e Desigualdades no Brasil Rural; Oxfam Brasil: Sao Paulo, Brasil, 2016.

144. Kiai, M. Report of the Special Rapporteur on the Rights to Freedom of Peaceful Assembly and of Association; A/HRC/29/25; Human Rights Council, United Nations: New York, NY, USA, 2015.

145. Appelbaum, R.; Bonacich, E.; Quan, K. The End of Apparel Quotas: A Faster Race to the Bottom? In Institute for Social, Behavioral, and Economic Research, Center for Global Studies; University of California: Santa Barbara, CA, USA, 2005.

146. Mousseau, F. The Highest Bidder Takes It All: The World Bank's Scheme to Privatize the Commons; The Oakland Institute: Oakland, CA, USA, 2019.

147. World Bank. Enabling the Business of Agriculture 2017; World Bank Group: Washington, DC, USA, 2017.

148. Martin-Prével, A.; Mousseau, F. The Unholy Alliance: Five Western Donors Shape a Pro-Corporate Agenda for African Agriculture; The Oakland Institute: Oakland, CA, USA, 2016. 
149. Willoughby, R. Moral Hazard? Mega Public-Private Partnerships in African Agriculture; Oxfam International: Oxford, UK, 2014.

150. Front Line Defenders. Front Line Defenders Global Analysis 2018; Front Line, the International Foundation for the Protection of Human Rights Defenders: Dublin, Ireland, 2019.

151. Geary, K. Our Land, our Lives: Time out on the Global Land Rush; Oxfam International: Oxford, UK, 2012.

152. West, J.J. Agricultural Investments for Development in Tanzania: Reconciling Actors, Strategies and Logics? Norwegian University of Life Sciences, Faculty of Landscape and Society: Akershus, Norway, 2017.

153. CCSI. Land Deal Dilemmas: Grievances, Human Rights, and Investor Protections; Columbia Center on Sustainable Investment: Bogota, Columbia, 2016.

154. Tauli-Corpuz, V. The impact of international investment and free trade on the human rights of indigenous peoples. In Report to the General Assembly A/70/301; United Nations: New York, NY, USA, 2015.

155. Cotula, L. Land Rights and Investment Treaties: Exploring the interface London, UK; International Institute for Environment and Development and Columbia Center on Sustainable Investment: London, UK, 2015.

156. Pérez, J.; Gistelinck, M.; Karbala, D. Sleeping Lions: International investment treaties, state-investor disputes and access to food, land and water. In Oxfam Policy and Practice: Agriculture, Food and Land; Oxfam: Oxford, UK, 2011.

157. Bernasconi-Osterwalder, N.; Smaller, C. Farmland Investments Are Finding their Way to International Arbitration. In International Institute for Sustainable Development; IISD: Winnipeg, ON, Canada, 2017; Volume 2017.

158. Coleman, J.; Cordes, K. Not So Sweet: Tanzania Confronts Arbitration over Large-Scale Sugarcane and Ethanol Project. In Columbia Center on Sustainable Investment; Columbia Center on Sustainable Investment: New York, NY, USA, 2017; Volume 2017.

159. ICSID. EcoDevelopment in Europe AB \& Others v. United Republic of Tanzania (ICSID Case No. ARB/17/33). Available online: https://icsid.worldbank.org/en/Pages/cases/casedetail.aspx?caseno=ARB/17/33 (accessed on 3 February 2019).

160. Masih, N. India Orders Staggering Eviction of 1 Million Indigenous People. In Some Environmentalists are Cheering; Washington Post: Washington, DC, USA, 2019.

161. Vidal, J. The Tribes Paying the Brutal Price of Conservation. The Guardian, 28 August 2016. Available online: https://www.theguardian.com/global-development/2016/aug/28/exiles-human-cost-of-conservationindigenous-peoples-eco-tourism (accessed on 27 March 2020).

162. RRI. Toward a Global Baseline of Carbon Storage in Collective Lands: An Updated Analysis of Indigenous Peoples' and Local Communities' Contributions to Climate Change Mitigation; Rights and Resources Initiative, Woods Hole Research Center, World Resources Institute, Eds.; Rights and Resources Initiative: Washington DC, USA, 2016.

163. Fratkin, E.; Mearns, R. Sustainability and pastoral livelihoods: Lessons from East African Maasai and Mongolia. Hum. Organ. 2003, 62, 112-122. [CrossRef]

164. Oostindie, H. Unpacking Dutch multifunctional agrarian pathways as processes of peasantisation and agrarianisation. J. Rural. Stud. 2018, 61, 255-264. [CrossRef]

165. Schneider, S.; van der Ploeg, J.D.; Hebinck, P. Reconsidering the contribution of nested markets to rural development. In Rural Development and the Construction of New Markets; Hebinck, P., van der Ploeg, J.D., Schneider, S., Eds.; Routledge: London, UK; New York, NY, USA, 2015; pp. 190-205.

166. Van der Ploeg, J.D.; Jingzhong, Y.; Schneider, S. Rural development through the construction of new, nested, markets: Comparative perspectives from China, Brazil and the European Union. J. Peasant. Stud. 2012, 39, 133-173. [CrossRef]

167. Hebinck, P.; Mtati, N.; Shackleton, C. More than just fields: Reframing deagrarianisation in landscapes and livelihoods. J. Rural. Stud. 2018, 61, 323-334. [CrossRef]

168. Satgar, V. The Solidarity Economy Alternative: The Crises of Global Capitalism and the Solidarity Economy Alternative; University of KwaZulu-Natal Press: Pietermaritzburg, South Africa, 2014.

169. Holt-Giménez, E.; Altieri, M.A. Agroecology, food sovereignty, and the new green revolution. Agroecol. Sustain. Food Syst. 2013, 37, 90-102.

170. Campesina, L.V. Defending Food Sovereignty. Available online: http://www.viacampesina.org/en/index.php/ organisation-mainmenu-44 (accessed on 6 July 2019). 
171. Regenvanu, R. The traditional economy as source of resilience in Vanuatu. In Defence of Melanesian Customary Land; Anderson, T., Lee, G., Eds.; Aid/Watch: Sydney, Australia, 2010; pp. 30-33.

172. Van der Ploeg, J.D. The New Peasantries: Struggles for Autonomy and Sustainability in an Era of Empire and Globalization; Earthscan: London, UK, 2008.

173. FAO. World Programme for the Census of Agriculture 2020. Volume 2 Operational Guidelines; FAO Statistical Development Series; Food and Agricultural Organization of the United Nations: Rome, Italy, 2018; p. 348.

174. FAO. World Programme for the Census of Agriculture 2020. Volume 1 Programme, Concepts and Definitions; FAO Statistical Development Series; Food and Agricultural Organization of the United Nations: Rome, Italy, 2017; p. 348.

175. IAEG-SDG. SDG Indicator 1.4.2 Metadata Document 12th February 2018; United Nations: New York, NY, USA, 2018; Available online: https://unstats.un.org/sdgs/metadata/files/Metadata-01-04-02.pdf (accessed on 27 March 2020).

176. IAEG-SDG. SDG Indicator 5.a.2 Metadata Document 12th February 2018; United Nations: New York, NY, USA, 2018; Available online: https://unstats.un.org/sdgs/metadata/files/Metadata-05-0A-02.pdf (accessed on 27 March 2020).

177. IAEG-SDG. SDG Indicator 5.a.1 Metadata Document 16th October 2017; United Nations: New York, NY, USA, 2017; Available online: https://unstats.un.org/sdgs/metadata/files/Metadata-05-0a-01.pdf (accessed on 27 March 2020).

(C) 2020 by the authors. Licensee MDPI, Basel, Switzerland. This article is an open access article distributed under the terms and conditions of the Creative Commons Attribution (CC BY) license (http://creativecommons.org/licenses/by/4.0/). 